\title{
Neurobehavioral disorders locked in Alcatraz: case reports on three famous inmates
}

\author{
Distúrbios neurocomportamentais presos em Alcatraz: relatos de caso em três famosos \\ presidiários
}

Hélio A. G. Teive, Luciano de Paola

\begin{abstract}
The Alcatraz prison, with its picturesque surroundings and fascinating life stories of its inmates, has been the subject of a number of films and publications. The authors take a closer look at the biographies of "Al Capone", Robert "Birdman" Stroud and "Mickey" Cohen. These legendary American mobsters shared not only a history at "The Rock", but also a history of neuropsychiatric diseases, ranging from neurosyphilis to anti-social, borderline and obsessive-compulsive personality disorders.
\end{abstract}

Keywords: neurosyphilis, personality disorder, obsessive compulsive disorder, criminal behavior.

RESUMO

A prisão de Alcatraz, com sua atmosfera pitoresca e as fascinantes histórias de seus prisioneiros, foi objeto de vários filmes e publicações. Os autores focam nas biografias de "Al Capone", Robert "Birdman" Stroud and "Mickey" Cohen. Estes legendários gangsteres americanos tem em comum não apenas suas penas cumpridas no "Rochedo", mas também uma história de doenças neuropsiquiátricas, de neurosífilis a personalidades anti-sociais, "borderline" e obsessivo-compulsivas.

Palavras-chave: neurosífilis, transtorno de personalidade, distúrbio obsessivo-compulsivo, comportamento criminal.

Criminal behavior and violence are considered as worldwide public health problems ${ }^{1}$. Criminal behavior has neurobiological basis. Recent studies have focused in this issue, emphasizing biological and psycho social deficits ${ }^{1,2}$. Different types of personality disorders, as borderline and antisocial personality disorder, have been related to violence and criminal behavior ${ }^{1,2,3,4,5}$. More recently, neuroscience principles and functional brain imaging were applied to better understand the neurobiology of psychopathy ${ }^{1,2}$. The aim of this historical review is to address these aspects using the Alcatraz island as background and revisiting the life histories and neuropsychiatric profiles of three of its most famous inmates.

\section{ALCATRAZ PRISON}

The Alcatraz prison was an important U.S. Federal Penitentiary, located in the Alcatraz island, at San Francisco bay, California'. In 1934, "The Rock”, as popularly known, was ranked as a maximum-security facility ${ }^{6}$. By the year of 1963, when officially closed, Alcatraz had housed famous prisoners including the very notorious American gangsters Alphonse "Scarface" Capone, Robert "Birdman" Stroud, and Meyer H. M. "Mickey" Cohen ${ }^{6,7}$.

\section{ALPHONSE "AL" CAPONE}

Alphonse Gabriel Capone (1899-1947) (Figure 1) was born in Brooklyn, New York, USA, to an immigrant Italian family ${ }^{6,7,8}$. He left school at age of 14, had different illegal jobs at the time and joined several teenagers' street gangs, being introduced to the crime scenario ${ }^{6,7,8}$. In 1919, Capone and his family moved to Chicago and "Al" started his illegal "businesses", including bootlegging (in the period known as "Prohibition"), gambling, prostitution and extortion ${ }^{6,7,8}$. He built a fortune and became "The big fellow in American crime", the "America's most famous gangster" and ultimately a "Mafia crime boss" 6,7,. After the Supreme Court ruling that illegal money was taxable, he was trialed guilty (for income tax evasion) and in 1931, was sentenced ten years in a federal prison. During his time in Alcatraz, Capone developed a clinical picture characterized

Universidade Federal do Paraná, Hospital de Clínicas, Serviço de Neurologia, Curitiba PR, Brazil.

Correspondence: Hélio A. G. Teive; Rua General Carneiro, 1103/102; 80060-150 Curitiba PR, Brasil; E-mail: hagteive@mps.com.br

Conflict of interest: There is no conflict of interest to declare.

Received 08 February 2015; Received in final form 29 March 2015; Accepted 22 April 2015. 
by mood swings (sometimes "magnanimous and jovial and then deflated and childish"), cognitive dysfunction (memory disorder, temporo-spatial disorientation), behavioral problems (irrational behavior and, sometimes, aggression), shuffling gait, dysarthria, and bradykinesia ${ }^{7.8}$. A neuro-psychiatric examination suggested that Capone had a previous psychopathic condition, without psychosis (probable antisocial personality disorder) and then neurosyphilis ${ }^{7}$. His personal health history suggested that he had endured a genital lesion in 1919 that eventually disappeared few days later, followed within two months by the development of a transient cutaneous rash all over the body, including hand and feet. A blood Wasserman reaction was positive ${ }^{7.8}$. He was treated with arsenic and bismuth injections. Back in Alcatraz, he refused both, a spinal tap and further treatment. However, he received courses of heavy metal injections, as well as, malarial therapy, all proved ineffective leading Capone to a route of progressive dementia associated with parkinsonism. In 1938, "typical Argyll-Robertson's pupils" were reported (general paresis of the insane) ${ }^{7}$. Capone evolved to present generalized tonic-clonic seizures, as his neurological condition continued to deteriorate.He was released to a hospital and finally to his family's Florida mansion. He died due to a stroke and pneumonia, in 1947, at the age of $48^{7,8}$.

\section{ROBERT F. "BIRDMAN" STROUD}

Robert Stroud (1890-1963) (Figure 2), the famous "birdman of Alcatraz", was born in Seatlle, USA, in $1890^{6,9}$. In 1909, at the age of 19, he brutally murdered a man who got involved with a prostitute, who happened to be Stroud's girlfriend. He was arrested and convicted of manslaughter, being sent to McNeil island, a federal penitentiary in Washington State ${ }^{6,9}$. Due to his violent behavior, impossible to manage conduct and threats toward other inmates, he was sent to the Leavenworth Federal penitentiary in Kansas ${ }^{6,9}$. In 1916 he stabbed a guard to death in front of 1,100 prisoners. His behavior was defined as "without remorse and lacked of conscience”. He was clinically diagnosed as a psychopath, with probable borderline or antisocial personality disorder, with high $\mathrm{IQ}^{6,9}$. During his time at Leavenworth, he started to study birds, particularly canaries, from 1920 until 1942. He was allowed to breed birds and maintain a lab inside the cell house. He managed to publish two books the topic, entitled "Diseases of Canaries" and "Stroud digest on the diseases of birds" and function as a real ornithologist ${ }^{6,9}$. Nonetheless, his behavior remained a major issue and in 1942 he was finally moved to Alcatraz, where he published two other books, entitled "Bobbie" and "Looking outward: a history of U.S prison system from colonial times to the formation of the bureau of Prisons". He died at the Springfield federal medical prison, in Missouri of heart failure on November 21, 1963, after 54 years of incarceration ${ }^{6,9}$.

\section{"MICKEY" COHEN}

Meyer Harris Michael “Mickey” Cohen (1913-1976) (Figure 3) was born in New York City (Brooklyn) and debuted in the crime scene early in his childhood years ${ }^{6,10}$. He was sent to a "special school for delinquents and mentally

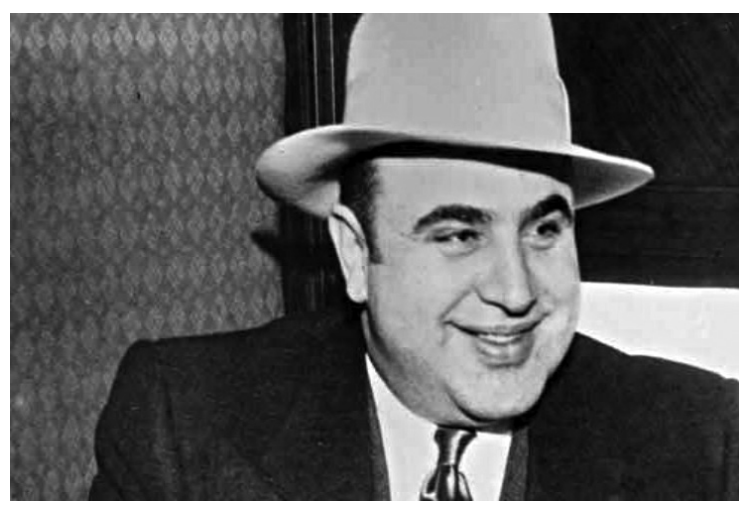

(Extracted from Google Images: Biography.com)

Figure 1. Alphonse "Scarface" Capone (1899-1947).

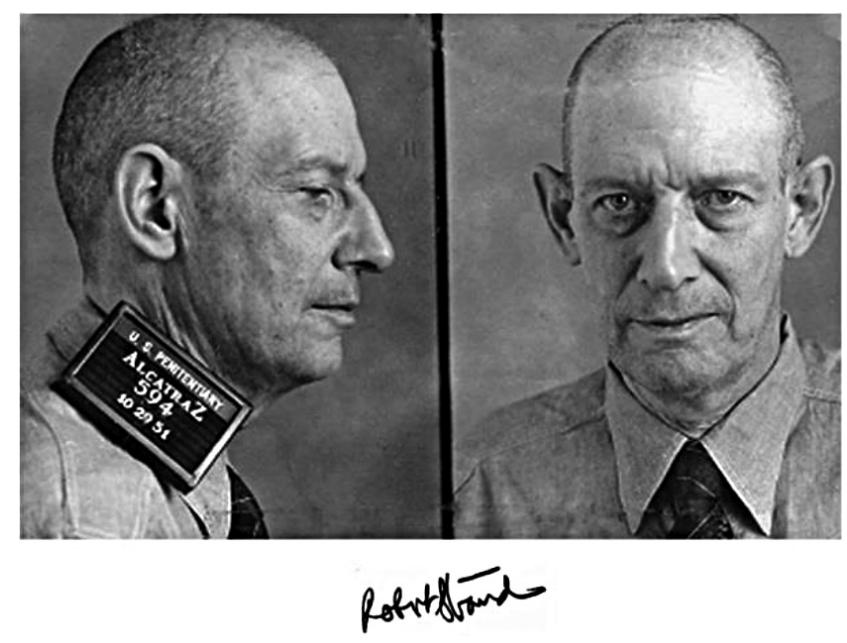

(Extracted from Google Images: Pixgood.com)

Figure 2. Robert "Birdman" Stroud (-1963).

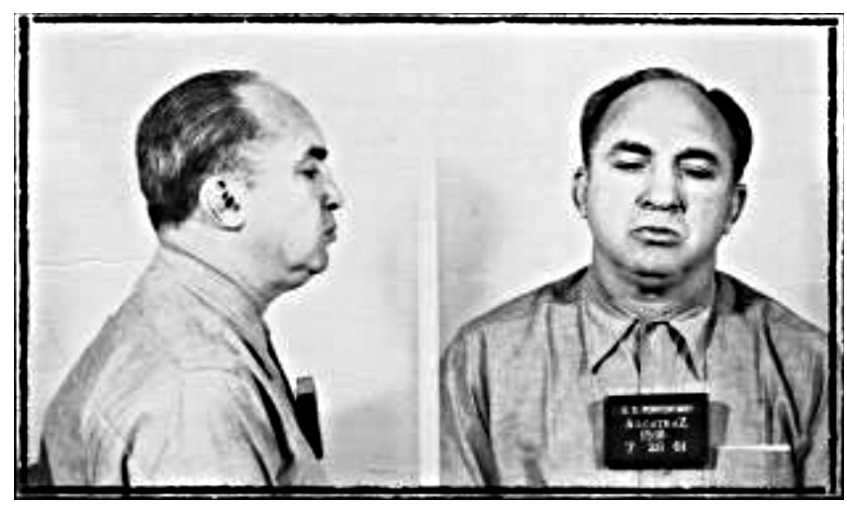

(Extracted from Google Images: Alcatrazhistory.com)

Figure 3. Meyer H.M. "Mickey" Coehn (1913-1976). 
retarded kids". At the age of 26, he went to Los Angeles to became "the Underworld Czar", "The Mini Mobster" and "Hollywood's celebrity gangster" ${ }^{6,10}$. His "businesses" included gambling, prostitution, illegal drugs, and sexual extortion. "Mickey" Cohen was arrested several times, and finally sentenced to prison due to income tax evasion ${ }^{6,10}$. His psychiatric evaluation defined him as an "uneducated man, with low IQ, with a severe obsessive-compulsive personality disorder". Cohen's biographical data demonstrated that pursued a collection of socks (more than 1,500), and hundreds of silk pajamas and neck ties. He also washed his hands every two or three minutes ${ }^{6,10}$. During his time in Alcatraz he took showers every hour and half, and used up to six rolls of toilet paper a day ${ }^{6,10}$. In prison "Mickey" Cohen had experienced a severe cranial trauma requiring neurosurgical approach, and developed a left hemiplegia. "Mickey" Cohen died in 1976, due to a stomach cancer ${ }^{6,10}$.

\section{CONCLUSION}

If the concept of a maximum security contemporary prison island just across the bay from one of the most beautiful cities in the world was not already a teaser, understanding the minds of some of the "America's most wanted" housed in there certainly sharpens one's curiosity. We presented a neurobehavioral perspective of Alcatraz, reviewing the life of three famous inmates, emphasizing their different neuro-psychiatric diseases and hopefully adding to an already fascinating plot.

\section{References}

1. Glenn AL, Raine A. The neurobiology of psychopathy.

Psychatr Clin North Am. 2008;31(3):463-75.

http://dx.doi.org/10.1016/j.psc.2008.03.004

2. Yang Y, Raine A. Prefrontal structural and functional brain imaging findings in antisocial, violent, and psychopathic individuals: a metanalysis. Psychiatry Res. 2009;174:81-8. http://dx.doi.org/10.1016/j.pscychresns.2009.03.012

3. Louzã Neto MR, Cordás TA. Transtornos de personalidade. Porto Alegre: Artmed; 2011

4. American Psychiatric Association. Manual diagnóstico e estatístico de transtornos mentais. DSM-5. 5@ Edição, Porto Alegre:Artmed; 2014.
5. Raine A. Features of borderline personality and violence.J Clin Psychol. 1993;49(2):277-81.

6. Kincade C. Alcatraz most wanted: profiles of the most famous prisoners on the rock. Berkeley: Ariel Vamp; 2008.

7. Brown MD. Capone: life behind bars at Alcatraz. San Francisco: Golden Gate National Parks Conservancy; 2004.

8. Schoenberg RJ. Mr. Capone. New York: HarperCollins; 1992.

9. Stroud RF. Looking outward. A voice from the grave. The Federal prison system from the inside. Springfield: Looking Outward; 2013.

10. Lewis B. Hollywood's celebrity gangster: the incredible life and times of Mickey Cohen. Los Angeles: BBL Books; 2007. 